\title{
Numerical Evaluation of the Impact of Urbanization on Summertime Precipitation in Osaka, Japan
}

\author{
Hikari Shimadera, ${ }^{1}$ Akira Kondo, ${ }^{2}$ Kundan Lal Shrestha, ${ }^{3}$ Ken Kitaoka, ${ }^{2}$ and Yoshio Inoue ${ }^{2}$ \\ ${ }^{1}$ Center for Environmental Innovation Design for Sustainability, Osaka University, 2-1 Yamadaoka, Suita, Osaka 565-0871, Japan \\ ${ }^{2}$ Graduate School of Engineering, Osaka University, 2-1 Yamadaoka, Suita, Osaka 565-0871, Japan \\ ${ }^{3}$ School of Science, Kathmandu University, Dhulikhel, Kavrepalanchok 45200, Nepal \\ Correspondence should be addressed to Hikari Shimadera; shimadera@ceids.osaka-u.ac.jp
}

Received 4 July 2014; Revised 2 September 2014; Accepted 2 September 2014

Academic Editor: Eduardo García-Ortega

Copyright (C) 2015 Hikari Shimadera et al. This is an open access article distributed under the Creative Commons Attribution License, which permits unrestricted use, distribution, and reproduction in any medium, provided the original work is properly cited.

\begin{abstract}
This study utilized the Weather Research and Forecasting (WRF) model version 3.5.1 to evaluate the impact of urbanization on summertime precipitation in Osaka, Japan. The evaluation was conducted by comparing the WRF simulations with the present land use and no-urban land use (replacing "Urban" with "Paddy") for August from 2006 to 2010. The urbanization increased mean air temperature by $2.1^{\circ} \mathrm{C}$ in urban areas because of increased sensible heat flux and decreased mean humidity by $0.8 \mathrm{~g} \mathrm{~kg}^{-1}$ because of decreased latent heat flux. In addition, the urbanization increased duration of the southwesterly sea breeze. The urbanization increased precipitation in urban areas and decreased in the surrounding areas. The mean precipitation in urban areas was increased by $20 \mathrm{~mm} \mathrm{month}{ }^{-1}$ ( $27 \%$ of the total amount without the synoptic-scale precipitation). The precipitation increase was generally due to the enhancement of the formation and development of convective clouds by the increase in sensible heat flux during afternoon and evening time periods. The urbanization in Osaka changes spatial and temporal distribution patterns of precipitation and evaporation, and consequently it substantially affects the water cycle in and around the urban areas of Osaka.
\end{abstract}

\section{Introduction}

Since the last century, rapid urbanization has spread across the world. The associated land cover alteration has resulted in the change of the surface energy budget and the local climate in urban areas. The well-recognized impact of urbanization is the urban heat island (UHI) effect characterized by higher temperature in urban areas relative to their surrounding areas. The UHI effect may influence local circulation patterns and precipitation events [1].

A number of studies have investigated the urbanization impact on precipitation based on analyses of observation data. Changnon and Huff [2] analyzed precipitation patterns during the Metropolitan Meteorological Experiment (METROMEX) in St. Louis, USA, and indicated that urban region influenced afternoon and nocturnal heavy precipitation events. Shepherd [3] analyzed 108-year precipitation data in arid urban areas of Phoenix, USA, and revealed statistically significant increases in precipitation during monsoon season from a preurban (1895-1949) to posturban (19502003) period. Fujibe et al. [4] analyzed the long-term trend of observed precipitation in Tokyo, Japan, and showed an increasing trend of precipitation in the afternoon of the warm season due to the UHI effect.

Numerical studies using meteorological models also have investigated the urbanization impact. Shem and Shepherd [5] simulated convective precipitation for two cases in Atlanta, USA, and showed that urban areas caused precipitation increase at downwind of the city by 10 to $13 \%$. Zhang et al. [6] evaluated the urbanization impact in the Yangtze River Delta of China and showed that precipitation increased about $15 \%$ over urban or leeward areas in summer and changed slightly in winter. Zhao et al. [7] simulated the impact of future urbanization in the Pearl River Delta of China and showed an important role of the urban area in enhancing the convective circulation over the region.

Although there are many studies on the urbanization impact on precipitation as described above, the mechanism 


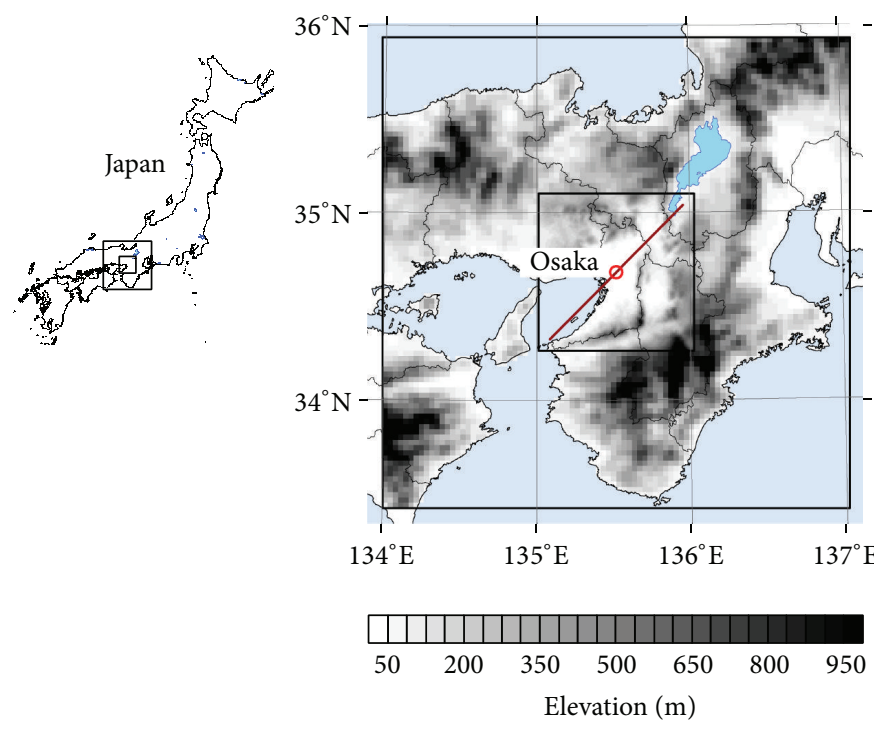

(a)

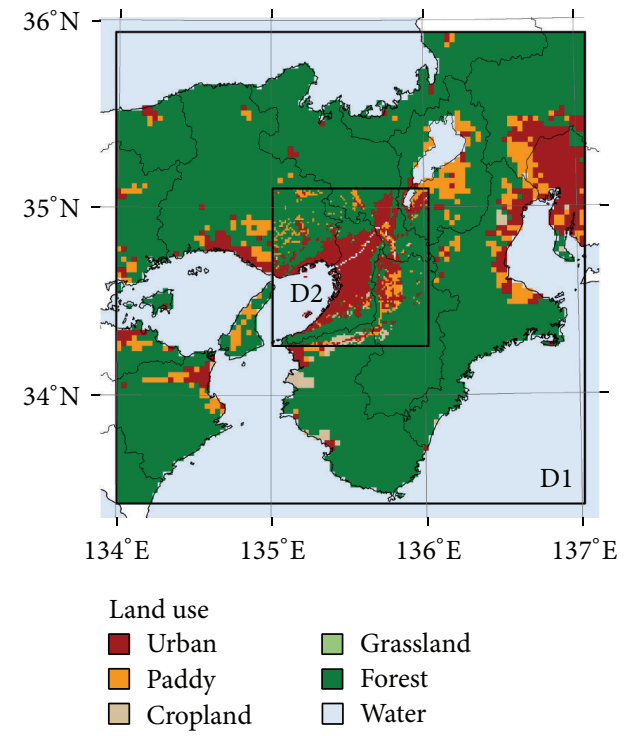

(b)

FIGURE 1: Modeling domains with elevation, location of Osaka meteorological observatory, and southwest to northeast cross-section line (a) and with dominant land use (b).

on the urban-induced precipitation is less understood compared to that on the urban-induced higher temperature. Therefore, further studies are still required to improve the basic understanding of urban-induced precipitation.

This study evaluated the urbanization impact on summertime precipitation in Osaka using the Weather Research and Forecasting (WRF) model [8] version 3.5.1. In August, in Osaka, the mean ground-level air temperature reaches nearly $30^{\circ} \mathrm{C}$ and the daily maximum value often exceeds $35^{\circ} \mathrm{C}$. Osaka prefecture includes the third largest megacity in Japan and is characterized by a small fraction of forest areas and particularly high fraction of urban areas. Because Osaka shows the largest UHI intensity among large Asian cities [9], this study contributes to a better understanding of the impact of urbanization on precipitation.

\section{Materials and Methods}

2.1. Study Area. This study focused on the urbanization impact on summertime precipitation in Osaka, Japan. Figure 1 shows the WRF modeling domains on the Lambert conformal conic projection map. Domain 1 (D1) and domain 2 (D2) cover the Kinki Region of Japan and areas in and around Osaka Prefecture, respectively. The WRF performance was evaluated with observation data of the Japan Meteorological Agency (JMA) at the Osaka meteorological observatory, which is located at $135.518^{\circ} \mathrm{E}$ and $34.682^{\circ} \mathrm{N}$ in the center of the prefecture. Topography and land use in the modeling domains were derived from the $30 \mathrm{sec}$ resolution data of the United States Geological Survey (USGS) and the $100 \mathrm{~m}$ resolution National Land Numerical Information data of the Geospatial Information Authority of Japan (GIAJ), respectively. While most parts of the land areas of the Kinki region are mountains covered with "Forest" land use, some coastal lowlands are dominantly covered with "Urban" land use. Since Osaka has a particularly high fraction of "Urban" land use, the Osaka prefecture is suitable for this study.

2.2. WRF Configuration. The WRF simulations were conducted with on-line one-way nesting in the two domains (Figure 1). The horizontal grid resolutions and the number of grid cells in the domains are 3 and $1 \mathrm{~km}$ and $90 \times 90$ and $90 \times$ 90 for D1 and D2, respectively. The vertical layers consisted of 30 sigma-pressure coordinated layers from the surface to $100 \mathrm{hPa}$ with the middle height of the first layer being approximately $28 \mathrm{~m}$. The land use dependent parameters for "Urban," "Paddy," "Cropland," "Grassland," "Forest," and "Water" categories (Figure 1(b)) were derived from the WRFdefault parameters for "Urban and Built-Up Land," "Irrigated Cropland and Pasture," "Cropland/Grassland Mosaic," "Grassland," "Mixed Forest," and "Water Bodies" categories in the USGS 24-category land use data, respectively.

Initial and lateral boundary conditions were derived from the mesoscale model grid point value (MSM GPV) data by JMA. Sea surface temperature was derived from the high-resolution, real-time, global sea surface temperature analysis data (RTG_SST_HR) by the US National Centers for Environmental Prediction (NCEP). Variables on the ground and in soil layers were derived from the final operational global analysis data by NCEP (NCEP FNL). The MSM GPV data have spatial resolutions of $0.0625^{\circ}$ (longitude) $\times$ $0.05^{\circ}$ (latitude) for surface data and $0.125^{\circ}$ (longitude) $\times 0.1^{\circ}$ (latitude) for pressure level data and a temporal resolution of 3 hours. The RTG_SST_HR data have a spatial resolution of $0.0833^{\circ}$ and a temporal resolution of 24 hours. The NCEP FNL data have a spatial resolution of $1^{\circ}$ and a temporal resolution of 6 hours. The four-dimensional data assimilation technique was not applied to the WRF simulations. 
The physics options used in this study include the Yonsei University scheme [10] for the planetary boundary layer (PBL) parameterization, the WRF single-moment 6-class microphysics scheme [11], the Noah land surface model [12], the rapid radiative transfer model [13] for the longwave radiation, and the Dudhia scheme [14] for the shortwave radiation. The cumulus parameterization was not activated because of the fine horizontal grid resolutions. The urban canopy model (UCM) was not used based on our preliminary test runs in which UCM caused questionable results such as stronger surface wind speed than that in runs without UCM (not shown).

2.3. Method for Evaluating the Impact of Urbanization. The impact of urbanization was evaluated by comparing the following two simulation cases: the baseline case with the present land use data shown in Figure 1(b) and the case with modified land use data in which "Urban" land use was replaced by "Paddy" land use in D2. The former and the latter cases are, respectively, referred to as URBAN and U2PAD cases in this paper. The two simulation cases were conducted for August of five years from 2006 to 2010 with three-day spin-up periods from July 29 to 31.

The target region for the evaluation of urbanization impact was defined as the "Urban" dominant grid cells in the URBAN case in D2 except near the lateral boundaries (distance of six grid cells). Because this study focused on local-scale urbanization impact on precipitation, days on which a weather front and/or tropical cyclone controlled meteorological conditions in the target region were excluded from the target period in order to minimize the effect of synoptic-scale precipitation. The excluded days were those on which a weather front stayed over or passed through D1 according to weather maps released by JMA and/or the minimum distance between the center of a tropical cyclone and the lateral boundaries of D1 was less than $300 \mathrm{~km}$. Based on the definition, the target period included 22, 21, 19, 22, and 29 days in August of 2006, 2007, 2008, 2009, and 2010, respectively (total 113 days out of 155).

\section{Results and Discussion}

3.1. Model Performance. The results of the WRF simulation in the URBAN case were compared with observation data at the Osaka meteorological observatory. The model performance was evaluated using Pearson's correlation coefficient $(r)$, the mean bias error (MBE), the mean absolute error (MAE), the root mean square error (RMSE), and the index of agreement (IA). Emery et al. [15] set benchmarks with statistical measures for the performance of meteorological models: $\mathrm{MBE} \leq \pm 0.5^{\circ} \mathrm{C}, \mathrm{MAE} \leq 2^{\circ} \mathrm{C}$, and $\mathrm{IA} \geq 0.8$ for air temperature; $\mathrm{MBE} \leq \pm 1 \mathrm{~g} \mathrm{~kg}^{-1}, \mathrm{MAE} \leq 2 \mathrm{~g} \mathrm{~kg}^{-1}$, and $\mathrm{IA} \geq 0.6$ for humidity; $\mathrm{MBE} \leq \pm 0.5 \mathrm{~m} \mathrm{~s}^{-1}, \mathrm{RMSE} \leq 2 \mathrm{~m} \mathrm{~s}^{-1}$, and IA $\geq 0.6$ for wind speed. Table 1 summarizes statistical values for the WRF performance at the Osaka meteorological observatory in August from 2006 to 2010. For air temperature, the model tended to overestimate it but met the benchmark for MAE and IA in all the five years. For humidity, the model met all the benchmark in all the five years. For wind speed, the model met all the benchmark in all the five years except $M B$ in 2009. These results and the good correlation coefficients between the observed and simulated values indicate that WRF well simulated meteorological fields in the study period and therefore was suitable for the evaluation of urbanization impact. The WRF performance in this study is comparable to the performance of meteorological models for one- to twomonth-long simulations in Japan in the earlier studies $[16,17]$.

Figure 2 shows hourly time series comparisons of the observed and simulated ground-level meteorological variables in August 2010, in which the number of the target days for the evaluation of urbanization impact was the largest among the five years. The simulated temporal variations of air temperature, humidity, wind speed, and direction in the URBAN case fairly well agreed with the observations. In summer, meteorological conditions in the main island of Japan are typically controlled by the Pacific high-pressure system prevailing over the Northwest Pacific Ocean. Local sea and land breeze circulations are well developed under the condition. In August, in Osaka, air temperature is consistently high and often exceeds $35^{\circ} \mathrm{C}$. In addition, humidity is also consistently high because substantial amount of moisture is supplied from the ocean. As shown in Figures 2(c) and 2(d), while the daytime southwesterly sea breeze generally prevails in Osaka, the nocturnal northeasterly land breeze is generally weak and sometimes calm. Although WRF well simulated temperature, humidity, and wind field, the model had difficulty in accurately simulating precipitation in August at the Osaka meteorological observatory. The result indicates that there are large uncertainties in numerical evaluations of summertime precipitation only at specific point and/or time. Therefore, this study evaluated the impact of urbanization for the target region and period defined in Section 2.3.

3.2. Impact of Urbanization. Figure 3 shows spatial distributions of the simulated mean ground-level meteorological variables in the URBAN case and the differences between the URBAN and U2PAD cases in the target period. The differences indicate the impact of urbanization. The urbanization caused obvious increase of air temperature in the target region and slight increase in the surrounding region. The mean impact of urbanization on air temperature, which is equivalent to the UHI intensity, was $+2.1^{\circ} \mathrm{C}$ in the target region and period. At the same time, the urbanization caused obvious decrease of humidity in the target region and slight decrease in the surrounding region. The mean impact of urbanization on humidity was $-0.8 \mathrm{~g} \mathrm{~kg}^{-1}$ in the target region and period. The impact of urbanization on mean wind speed was not clear compared to air temperature and humidity. The mean impact of urbanization on wind speed was $+0.1 \mathrm{~m} \mathrm{~s}^{-1}$ in the target region and period. The urbanization caused an increase of precipitation in the target region and a decrease in the surrounding region. The mean impact of urbanization on precipitation was $+20 \mathrm{~mm} \mathrm{month}^{-1}$, which was equivalent to $27 \%$ of the total amount without the synoptic-scale precipitation, in the target region and period.

Figure 4 shows diurnal variations of the simulated mean ground-level meteorological variables in the URBAN and 
TABLE 1: Statistical comparisons between observed and simulated (URBAN) hourly meteorological variables at Osaka meteorological observatory in August from 2006 to 2010.

\begin{tabular}{|c|c|c|c|c|c|c|}
\hline & & 2006 & 2007 & 2008 & 2009 & 2010 \\
\hline \multirow{6}{*}{ Temperature } & Mean obs. $\left({ }^{\circ} \mathrm{C}\right)$ & 29.8 & 29.8 & 28.4 & 28.0 & 30.5 \\
\hline & Mean sim. $\left({ }^{\circ} \mathrm{C}\right)$ & 30.6 & 30.2 & 29.5 & 29.0 & 30.8 \\
\hline & $r$ & 0.91 & 0.91 & 0.91 & 0.89 & 0.93 \\
\hline & $\operatorname{MBE}\left({ }^{\circ} \mathrm{C}\right)$ & 0.8 & 0.3 & 1.1 & 1.0 & 0.3 \\
\hline & $\operatorname{MAE}\left({ }^{\circ} \mathrm{C}\right)$ & 1.1 & 0.8 & 1.3 & 1.3 & 0.7 \\
\hline & IA & 0.93 & 0.94 & 0.92 & 0.91 & 0.96 \\
\hline \multirow{6}{*}{ Humidity } & Mean obs. $\left(\mathrm{g} \mathrm{kg}^{-1}\right)$ & 16.6 & 16.6 & 15.9 & 15.4 & 17.2 \\
\hline & Mean sim. $\left(\mathrm{g} \mathrm{kg}^{-1}\right)$ & 15.9 & 16.4 & 15.9 & 15.1 & 17.2 \\
\hline & $r$ & 0.69 & 0.67 & 0.74 & 0.86 & 0.72 \\
\hline & $\operatorname{MBE}\left(\mathrm{g} \mathrm{kg}^{-1}\right)$ & -0.6 & -0.2 & 0.0 & -0.3 & 0.0 \\
\hline & $\operatorname{MAE}\left(\mathrm{g} \mathrm{kg}^{-1}\right)$ & 1.3 & 1.1 & 1.1 & 1.2 & 0.9 \\
\hline & IA & 0.79 & 0.80 & 0.86 & 0.92 & 0.84 \\
\hline \multirow{6}{*}{ Wind speed } & Mean obs. $\left(\mathrm{m} \mathrm{s}^{-1}\right)$ & 2.7 & 2.6 & 2.7 & 2.3 & 2.5 \\
\hline & Mean sim. $\left(\mathrm{m} \mathrm{s}^{-1}\right)$ & 2.7 & 2.8 & 3.1 & 2.9 & 2.7 \\
\hline & $r$ & 0.66 & 0.72 & 0.60 & 0.60 & 0.72 \\
\hline & $\operatorname{MBE}\left(\mathrm{m} \mathrm{s}^{-1}\right)$ & 0.0 & 0.2 & 0.3 & 0.6 & 0.2 \\
\hline & $\operatorname{RMSE}\left(\mathrm{m} \mathrm{s}^{-1}\right)$ & 1.3 & 1.2 & 1.4 & 1.3 & 1.0 \\
\hline & IA & 0.81 & 0.84 & 0.76 & 0.73 & 0.84 \\
\hline
\end{tabular}

Note: $r$, MBE, MAE, RMSE, and IA denote Pearson's correlation coefficient, the mean bias error, the mean absolute error, the root mean square error, and the index of agreement, respectively.

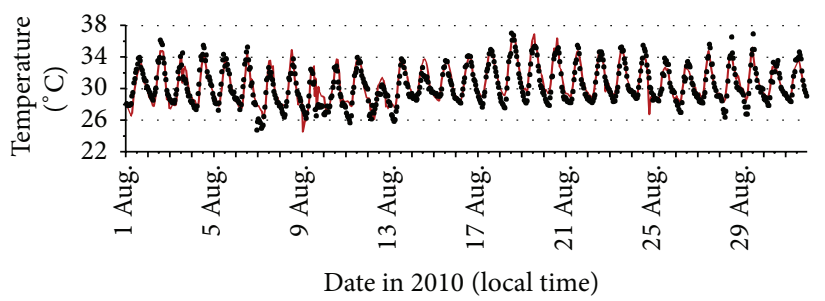

(a)

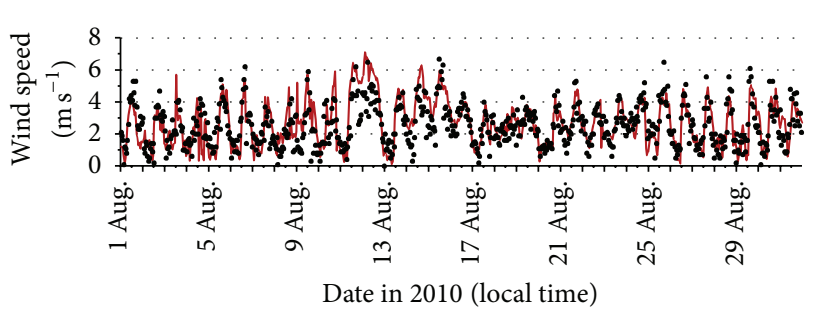

(c)

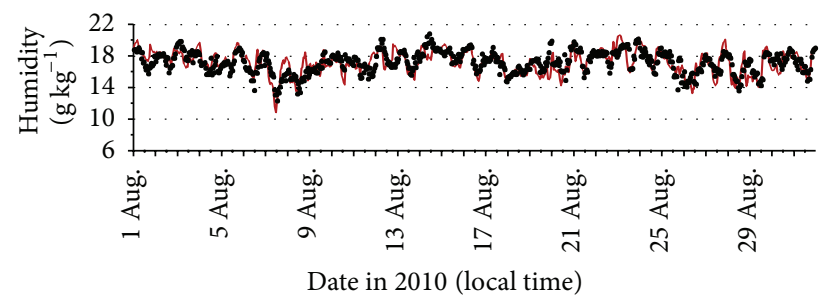

(b)

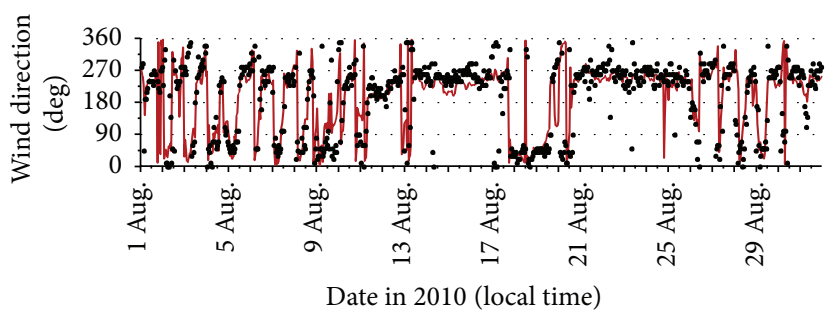

(d)

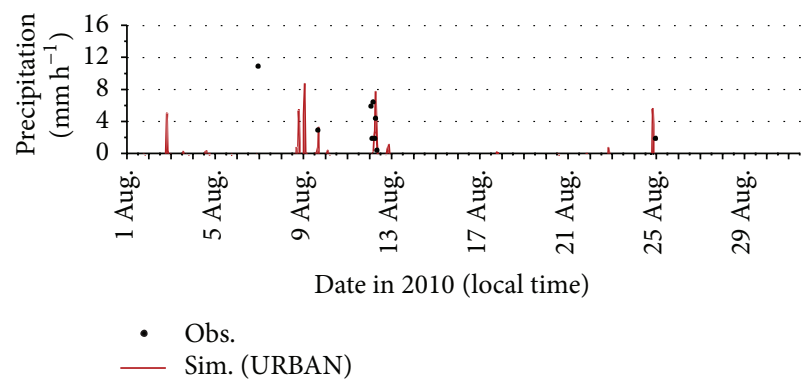

(e)

FIgURE 2: Hourly time series comparisons of observed and simulated (URBAN case) ground-level meteorological variables at Osaka meteorological observatory in August 2010. 

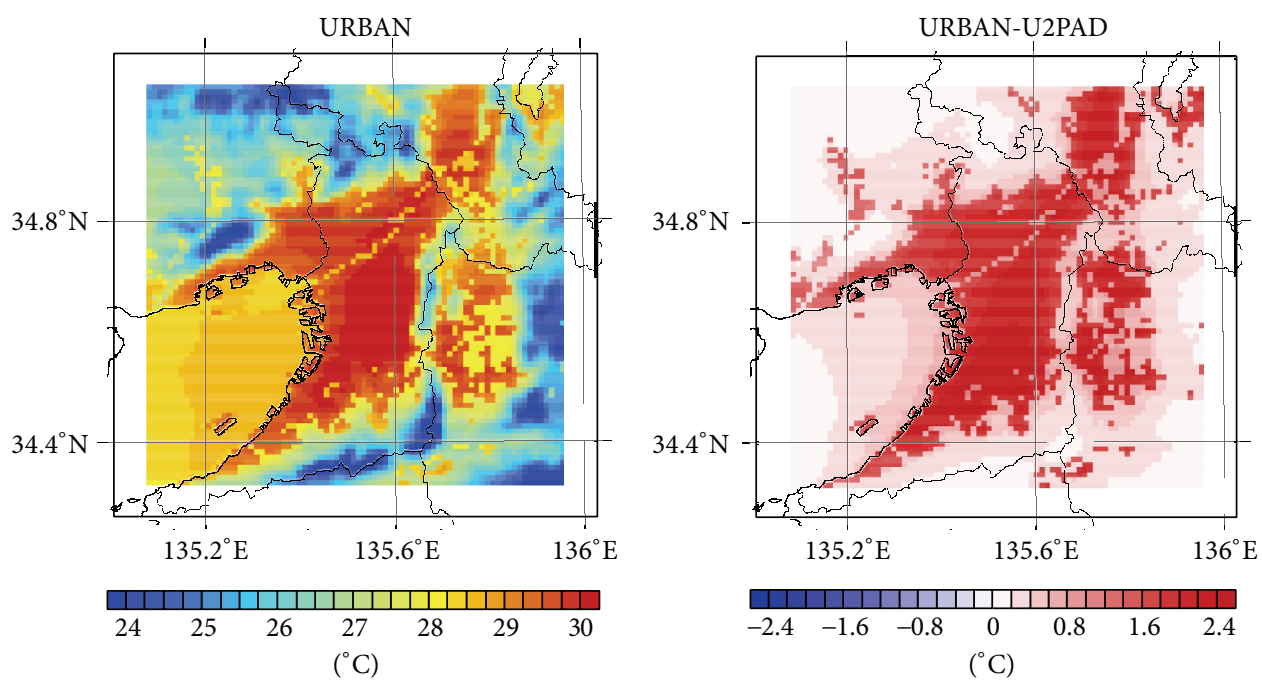

(a) Temperature
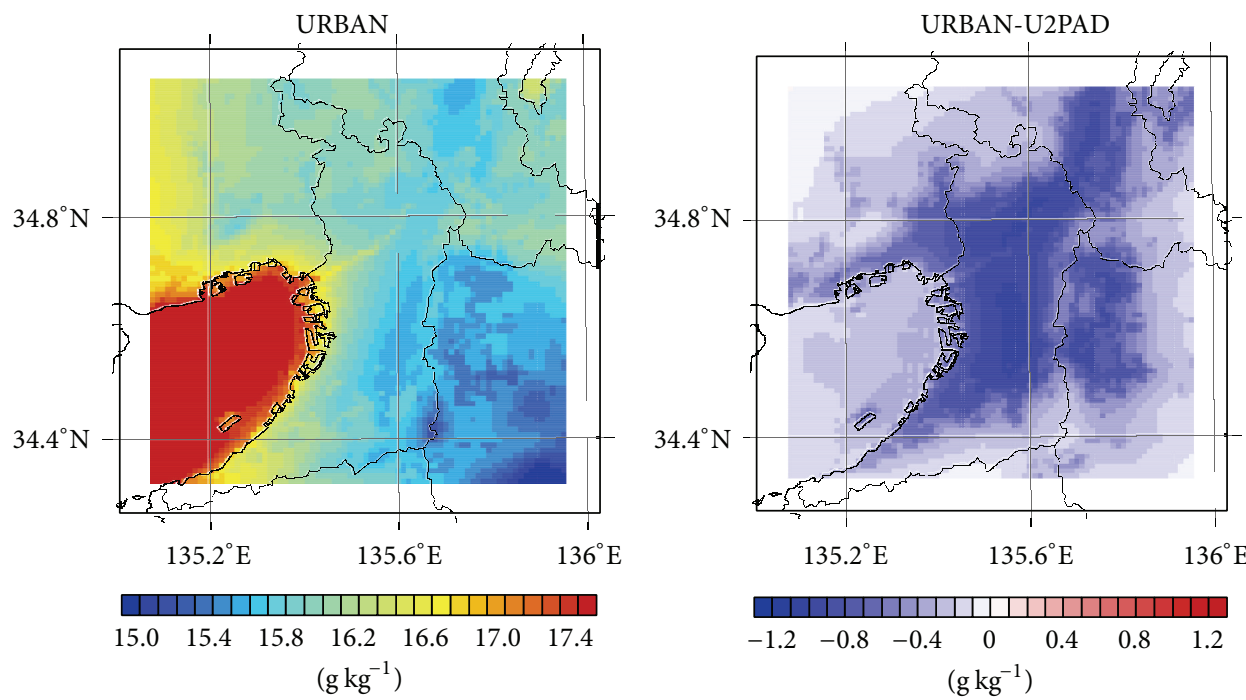

(b) Humidity
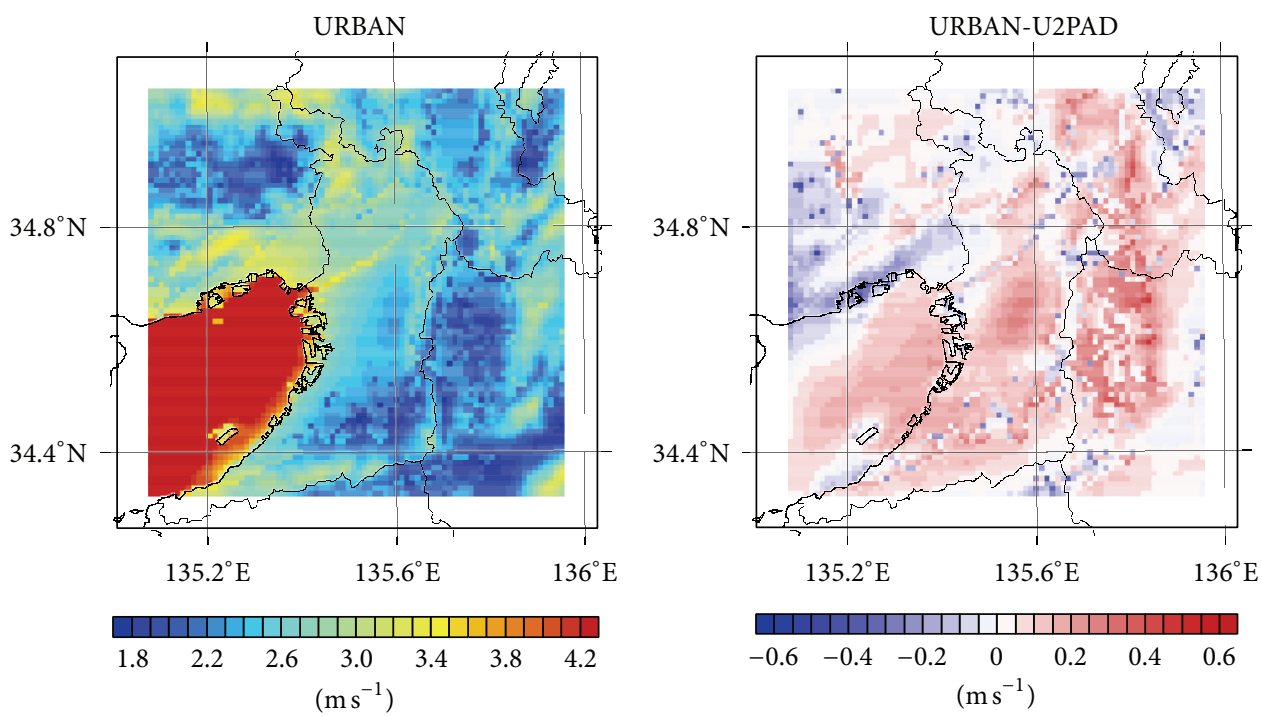

(c) Wind speed

FIgure 3: Continued. 

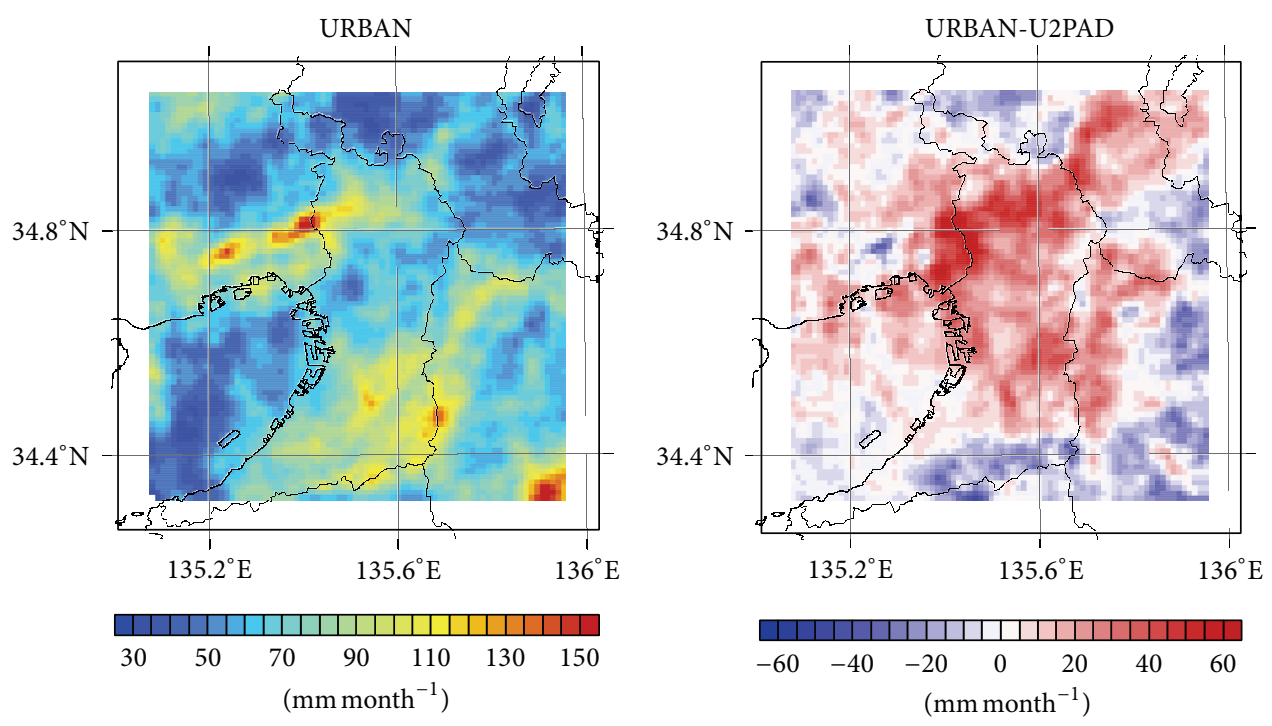

(d) Precipitation

FIGURE 3: Spatial distributions of simulated mean ground-level meteorological variables in URBAN case and the differences of the variables between URBAN and U2PAD cases in D2 in the target period for the evaluation of the impact of urbanization.

$\mathrm{U} 2 \mathrm{PAD}$ cases in the target region and period. The urbanization increased air temperature because of increased sensible heat flux. The increase from midnight to dawn was remarkable (up to $3.1^{\circ} \mathrm{C}$ at 0500 local time) because large part of the sensible heat was transported to the upper air by vertical mixing in daytime. In addition, a part of heat accumulated in soil layers in daytime was released to the atmosphere as sensible heat after sunset. The urbanization decreased humidity because of decreased evaporation from the surface, that is, latent heat flux (almost zero in "Urban" land use). The increased surface drag in "Urban" land use generally decreases ground-level wind speed. On the other hand, the increased ground-level air temperature enhanced sea breeze circulation, which resulted in longer duration of the southwesterly sea breeze in the target region. The above two effects compensated each other and therefore the apparent impact of urbanization on mean wind speed was relatively small as shown in Figure 3(c). The increased sensible heat flux caused remarkable increase of PBL height from noon to evening (up to $449 \mathrm{~m}$ at 1700 local time). This indicated that the atmosphere over "Urban" land use was relatively more unstable in the period and therefore convective clouds were more easily formed and developed. As a result, the urbanization caused obvious increase of precipitation from afternoon to evening. The results indicate that, in the target region, in which substantial amount of moisture is supplied from the ocean, the sensible heat flux plays a much more important role in summertime local precipitation than the evaporation from the ground surface.

Figure 5 shows vertical cross-sections of simulated mean potential temperature with wind fields in the URBAN and U2PAD cases at 1400, 1700, and 2000 local time in the target period. Vertical convection was generally stronger and PBL was consistently higher in the URBAN case than in the U2PAD case over the target region. Difference of upper air potential temperature between the URBAN and U2PAD cases was remarkable during afternoon, which indicates that the increased sensible heat from the surface (Figure 4(e)) was efficiently transported to the upper air through the enhanced vertical mixing over "Urban" land use. While the formation of nocturnal surface inversion layer in the target region was simulated in the U2PAD case, release of sensible heat accumulated during daytime prevented the formation of the stable layer in the URBAN case. Overall, the urbanization caused unstable condition in the atmosphere from afternoon to evening.

Figure 6 shows horizontal distributions of precipitation and vertical cross-sections of cloud water mixing ratio with wind field simulated in the URBAN and U2PAD cases at 1700 local time in August 9, 2008, as an example representing the difference between the two cases. In both cases, upward convection occurred by the convergence of horizontal wind in the north central region of Osaka prefecture. However, the atmosphere over the target region was more unstable in the URBAN case than in the U2PAD case, and therefore the convection in the former case was much deeper. As a result, clouds formed and developed by the enhanced convection increased precipitation in the target region. There were other similar cases in which the urbanization caused local-scale precipitation associated with convective clouds in the target region from afternoon to evening.

Figure 7 shows frequency distribution of hourly precipitation intensity at each grid cell in the URBAN and U2PAD cases in the target region and period. The frequency in the URBAN case was higher than that in the U2PAD case in every precipitation intensity class. The mean frequencies at grid cell in the target region and period for precipitation $\geq 0.5$ and $\geq 10 \mathrm{~mm} \mathrm{~h}^{-1}$ were 2.68 and $0.36 \%$ in the URBAN case and 


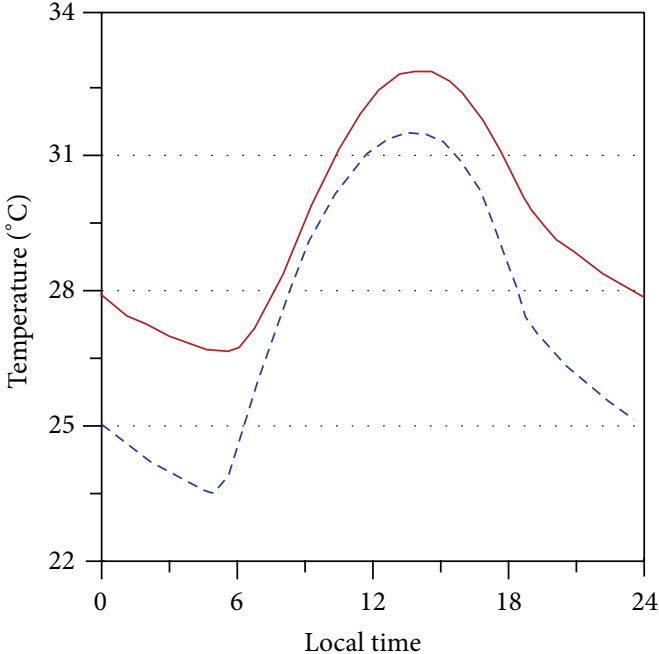

(a)

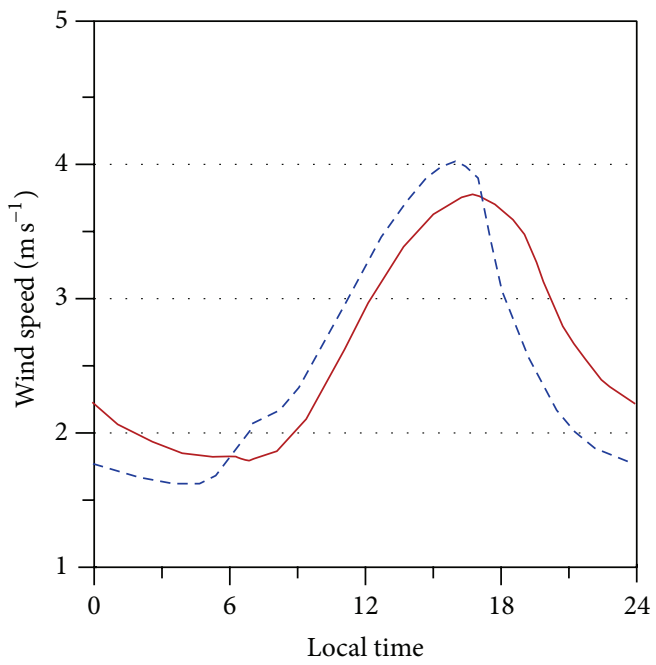

(c)

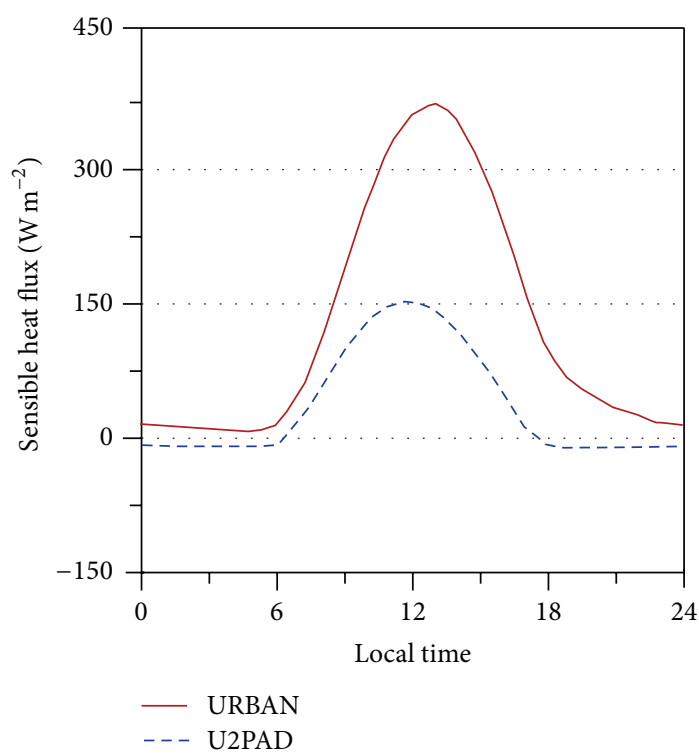

(e)

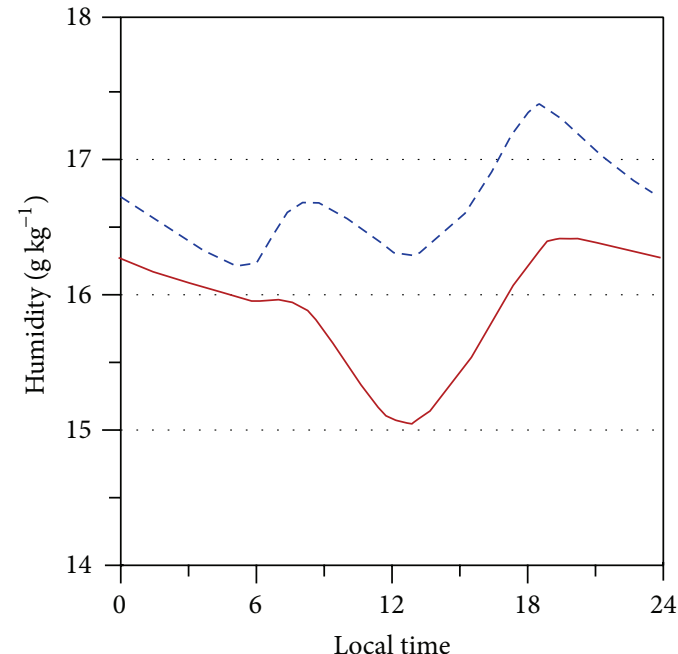

(b)

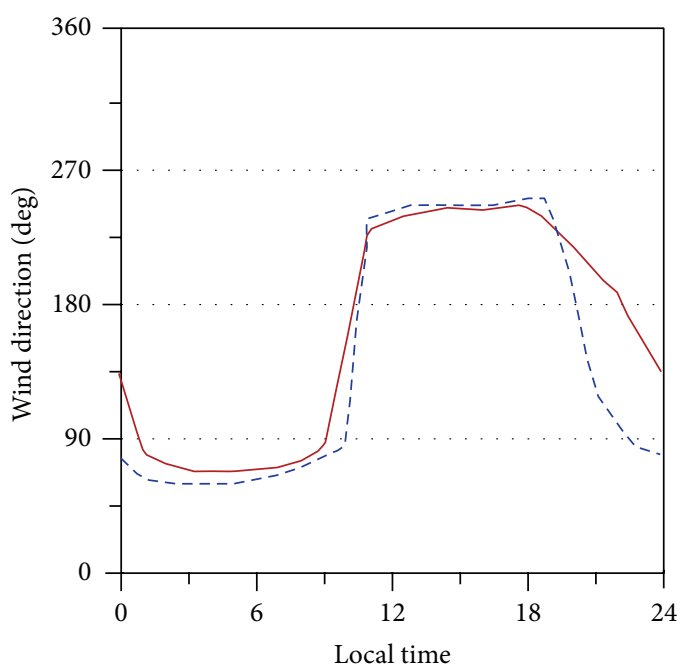

(d)

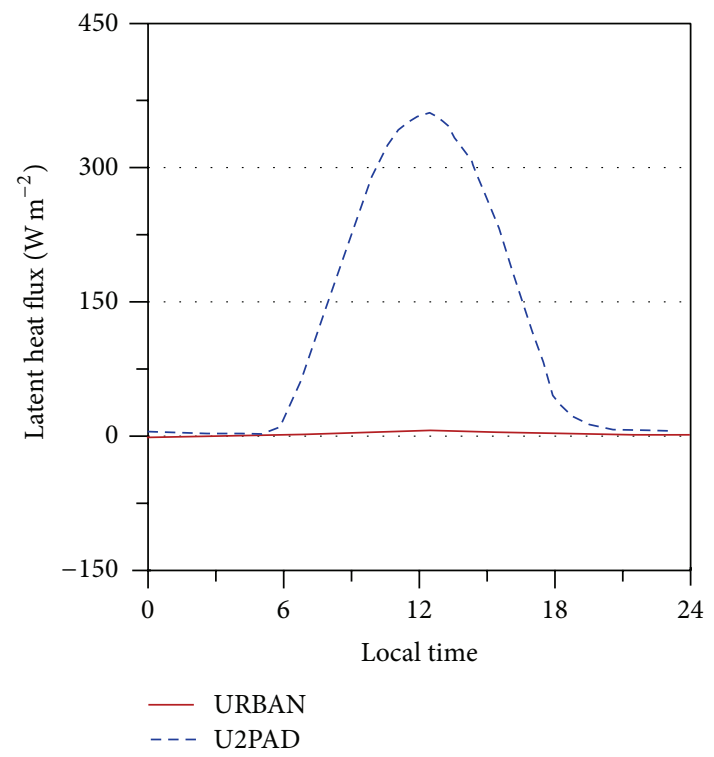

(f)

Figure 4: Continued. 


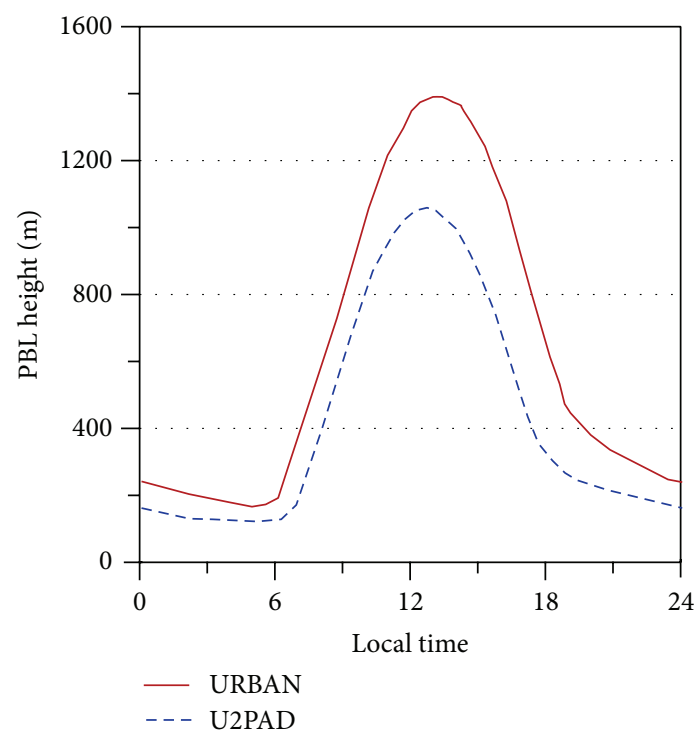

(g)

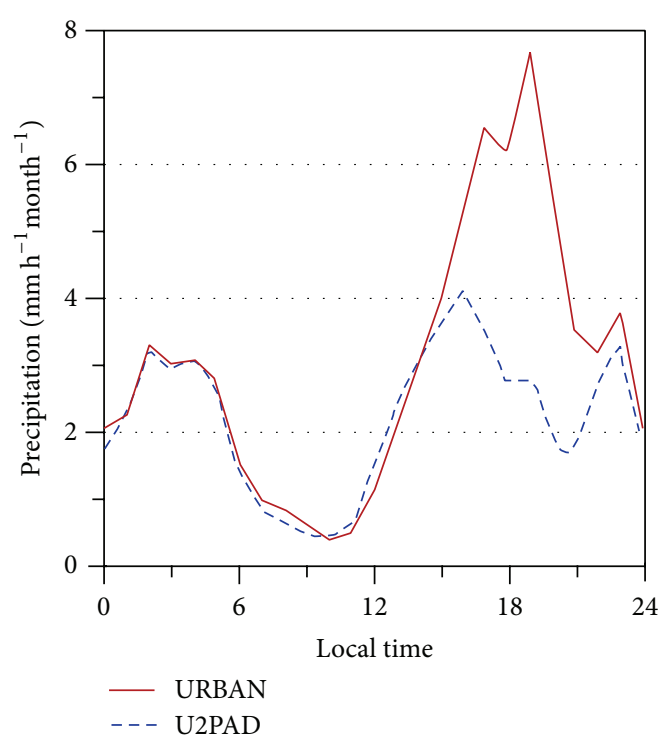

(h)

FIGURE 4: Diurnal variations of simulated mean ground-level meteorological variables in URBAN and U2PAD cases in the target region and period for the evaluation of the impact of urbanization.
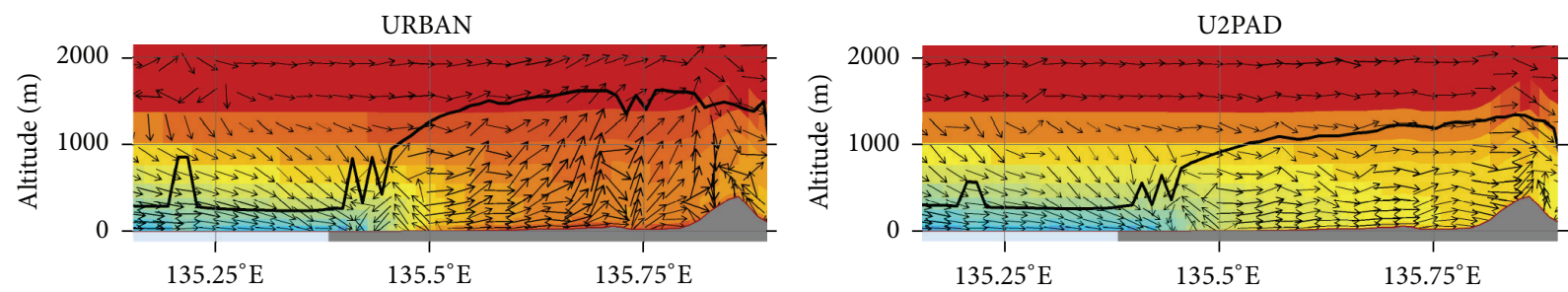

(a)
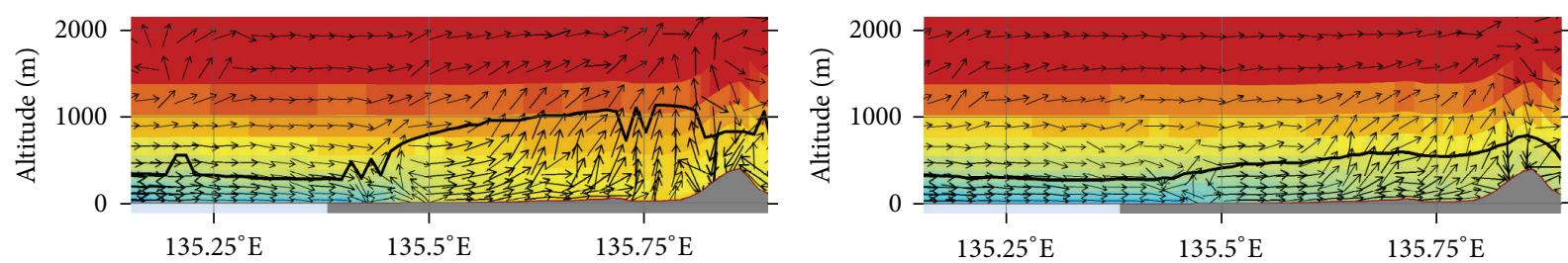

(b)
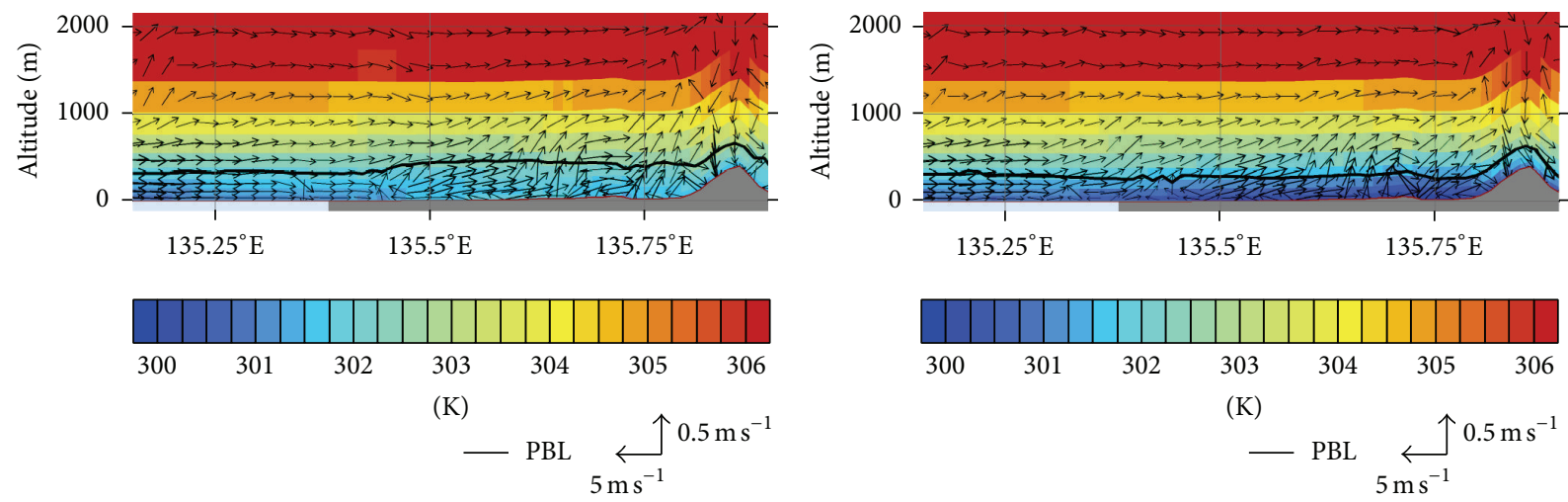

(c)

FIGURE 5: Vertical cross-sections of simulated mean potential temperature with wind field and PBL height along the southwest to northeast cross-section line in Figure 1(a) in URBAN and U2PAD cases at 1400 (a), 1700 (b), and 2000 (c) local time in the target period for the evaluation of the impact of urbanization. 


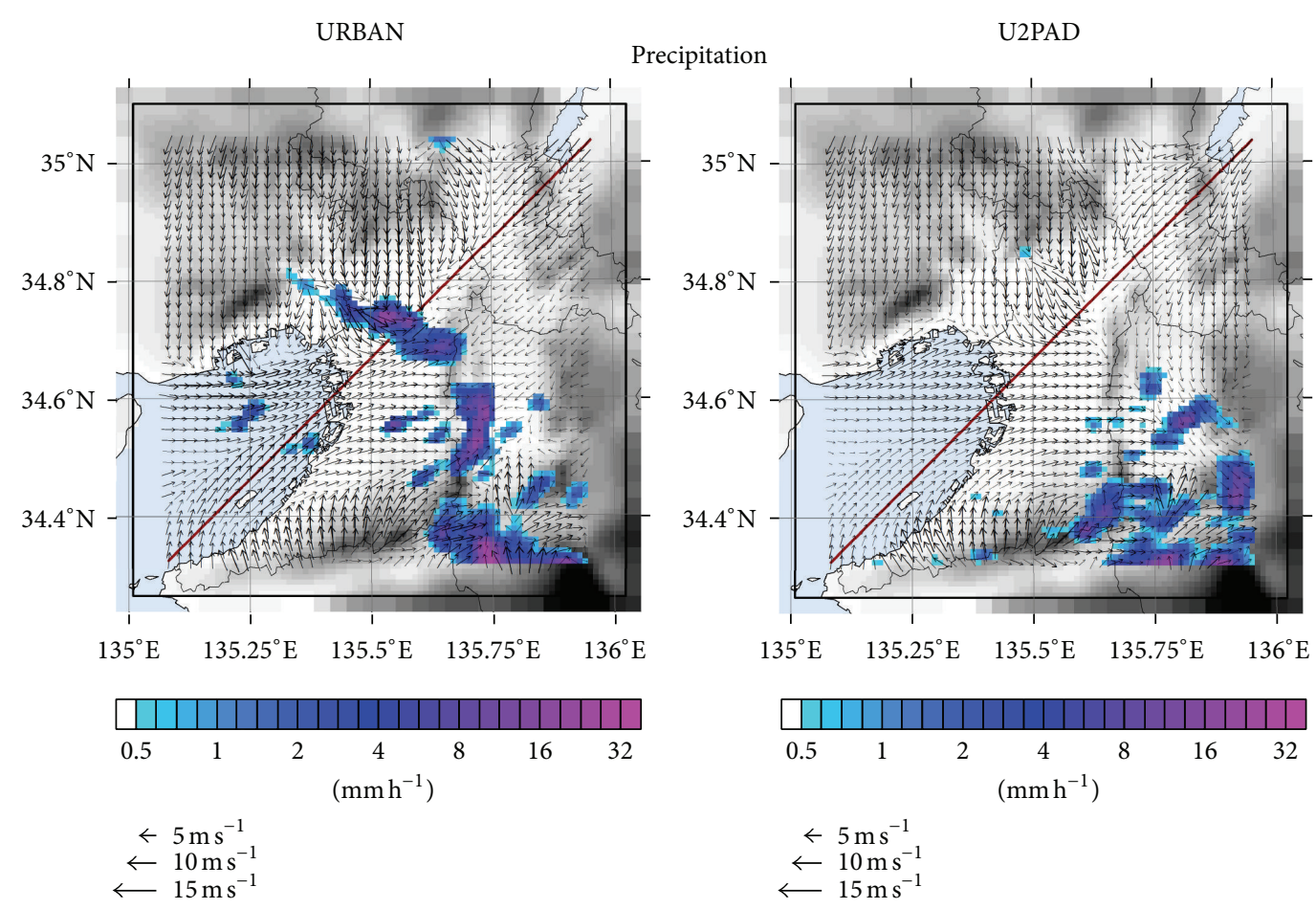

(a)

Cloud water mixing ratio
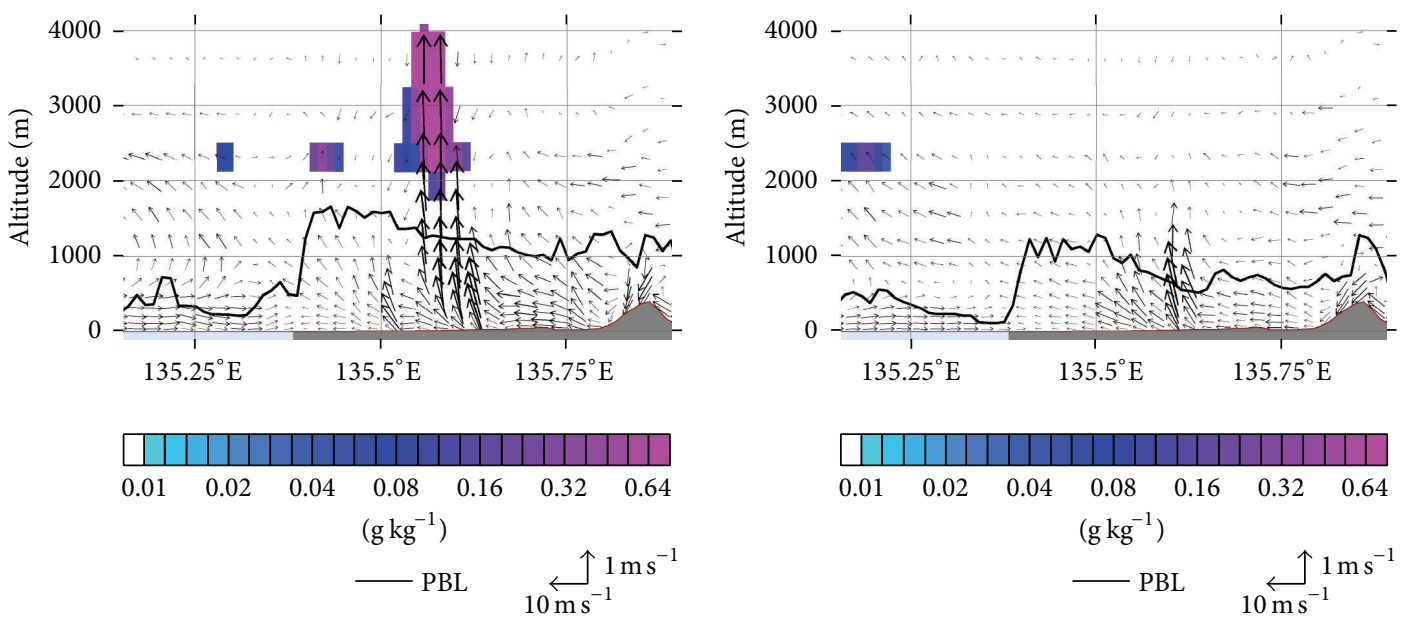

(b)

FIGURE 6: Horizontal distributions of simulated precipitation with ground-level wind field and vertical cross-sections of simulated cloud water mixing ratio with wind field and PBL height along the southwest to northeast cross-section line in Figure 1(a) in URBAN and U2PAD cases at 1700 local time in August 9, 2008.

2.17 and $0.25 \%$ in the U2PAD case, respectively. Therefore, the urbanization increased not only precipitation intensity but also precipitation duration.

\section{Conclusion}

This study evaluated the impact of urbanization on summertime precipitation in Osaka, Japan, by comparing the WRF simulations for August of five years from 2006 to 2010. The urbanization impact was evaluated by comparing the URBAN case with the present land use and the U2PAD case with modified land use data in which "Urban" was replaced by "Paddy." The target region for the evaluation was the "Urban" dominant grid cells in the URBAN case. The target period was the WRF simulation periods except for days with the synoptic-scale precipitation. The URBAN case well simulated the meteorological fields in Osaka, characterized by high temperature and humidity and relatively strong southwesterly sea breeze and weak northeasterly land breeze circulations.

The urbanization increased mean air temperature in the target region and period by $2.1^{\circ} \mathrm{C}$ because of the increased 


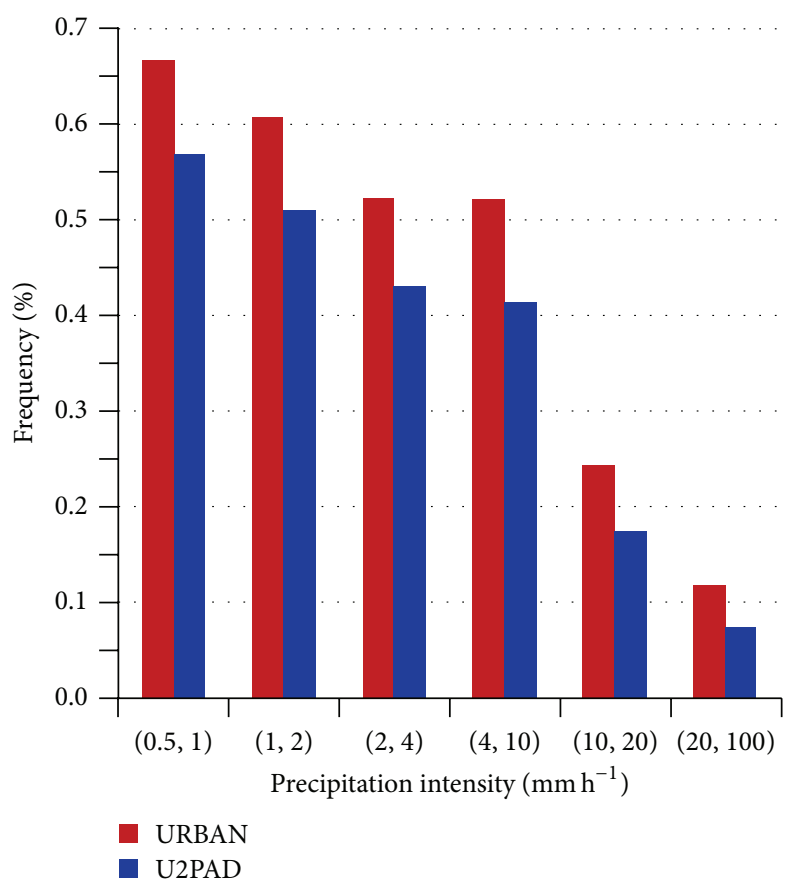

FIGURE 7: Frequency distribution of hourly precipitation intensity at each grid cell in URBAN and U2PAD cases in the target region and period for the evaluation of the impact of urbanization.

sensible heat flux. At the same time, the urbanization decreased mean humidity in the target region and period by $0.8 \mathrm{~g} \mathrm{~kg}^{-1}$ because of the decreased latent heat flux. The impact of urbanization on mean wind speed was not clear compared to air temperature and humidity. This is because the effect of increased surface drag was compensated by the enhanced sea breeze circulation. The urbanization caused an increase of precipitation in the target region and a decrease in the surrounding region. The mean precipitation in the target region and period was increased by $20 \mathrm{~mm} \mathrm{month}{ }^{-1}$, which was equivalent to $27 \%$ of the total amount without the synoptic-scale precipitation. In addition, the frequency in the URBAN case was higher than that in the U2PAD case in every precipitation intensity class, indicating that the urbanization increased not only precipitation intensity but also precipitation duration in the target region. The precipitation increase was generally due to the enhancement of the formation and development of convective clouds from afternoon to evening by the increased sensible heat flux. The results indicate that, in the target region, in which substantial amount of moisture is supplied from the ocean, the sensible heat flux plays a much more important role in summertime local precipitation than the evaporation from the ground surface. This study showed that the urban areas of Osaka substantially affected spatial and temporal distribution patterns of summertime precipitation and evaporation and consequently the water cycle in and around the areas.

\section{Conflict of Interests}

The authors declare that there is no conflict of interests regarding the publishing of this paper.

\section{Acknowledgment}

This research was supported by JSPS KAKENHI Grant nos. 26420581 and 26740038.

\section{References}

[1] J. M. Shepherd, "A review of current investigations of urbaninduced rainfall and recommendations for the future," Earth Interactions, vol. 9, no. 12, pp. 1-27, 2005.

[2] S. A. Changnon Jr. and F. A. Huff, "The urban-related nocturnal rainfall anomaly at St. Louis," Journal of Climate \& Applied Meteorology, vol. 25, no. 12, pp. 1985-1995, 1986.

[3] J. M. Shepherd, "Evidence of urban-induced precipitation variability in arid climate regimes," Journal of Arid Environments, vol. 67, no. 4, pp. 607-628, 2006.

[4] F. Fujibe, H. Togawa, and M. Sakata, "Long-term change and spatial anomaly of warm season afternoon precipitation in Tokyo," Scientific Online Letters on the Atmosphere, vol. 5, pp. 17-20, 2009.

[5] W. Shem and M. Shepherd, "On the impact of urbanization on summertime thunderstorms in Atlanta: two numerical model case studies," Atmospheric Research, vol. 92, no. 2, pp. 172-189, 2009.

[6] N. Zhang, Z. Gao, X. Wang, and Y. Chen, "Modeling the impact of urbanization on the local and regional climate in Yangtze River Delta, China," Theoretical and Applied Climatology, vol. 102, no. 3, pp. 331-342, 2010.

[7] C. Zhao, Q. Jiang, Z. Sun, H. Zhong, and S. Lu, "Projected urbanization impacts on surface climate and energy budgets in the pearl river delta of china," Advances in Meteorology, vol. 2013, Article ID 542086, 10 pages, 2013. 
[8] W. C. Skamarock and J. B. Klemp, "A time-split nonhydrostatic atmospheric model for weather research and forecasting applications," Journal of Computational Physics, vol. 227, no. 7, pp. 3465-3485, 2008.

[9] K. Kataoka, F. Matsumoto, T. Ichinose, and M. Taniguchi, "Urban warming trends in several large Asian cities over the last 100 years," Science of the Total Environment, vol. 407, no. 9, pp. 3112-3119, 2009.

[10] S.-Y. Hong, Y. Noh, and J. Dudhia, "A new vertical diffusion package with an explicit treatment of entrainment processes," Monthly Weather Review, vol. 134, no. 9, pp. 2318-2341, 2006.

[11] S.-Y. Hong and J.-O. J. Lim, "The WRF single-moment 6class microphysics scheme (WSM6)," Journal of the Korean Meteorological Society, vol. 42, pp. 129-151, 2006.

[12] F. Chen and J. Dudhia, "Coupling and advanced land surfacehydrology model with the Penn State-NCAR MM5 modeling system. Part I: model implementation and sensitivity," Monthly Weather Review, vol. 129, no. 4, pp. 569-585, 2001.

[13] E. J. Mlawer, S. J. Taubman, P. D. Brown, M. J. Iacono, and S. A. Clough, "Radiative transfer for inhomogeneous atmospheres: RRTM, a validated correlated-k model for the longwave," Journal of Geophysical Research D: Atmospheres, vol. 102, no. 14, pp. 16663-16682, 1997.

[14] J. Dudhia, "Numerical study of convection observed during the Winter Monsoon Experiment using a mesoscale twodimensional model," Journal of the Atmospheric Sciences, vol. 46, no. 20, pp. 3077-3107, 1989.

[15] C. Emery, E. Tai, and G. Yarwood, "Enhanced meteorological modeling and performance evaluation for two Texas ozone episodes," Prepared for the Texas Natural Resource Conservation Commission, Austin, Tex, USA, 2001.

[16] H. Shimadera, A. Kondo, A. Kaga, K. L. Shrestha, and Y. Inoue, "Contribution of transboundary air pollution to ionic concentrations in fog in the Kinki Region of Japan," Atmospheric Environment, vol. 43, no. 37, pp. 5894-5907, 2009.

[17] H. Shimadera, H. Hayami, Y. Morino et al., "Analysis of summertime atmospheric transport of fine particulate matter in Northeast Asia," Asia-Pacific Journal of Atmospheric Sciences, vol. 49, no. 3, pp. 347-360, 2013. 

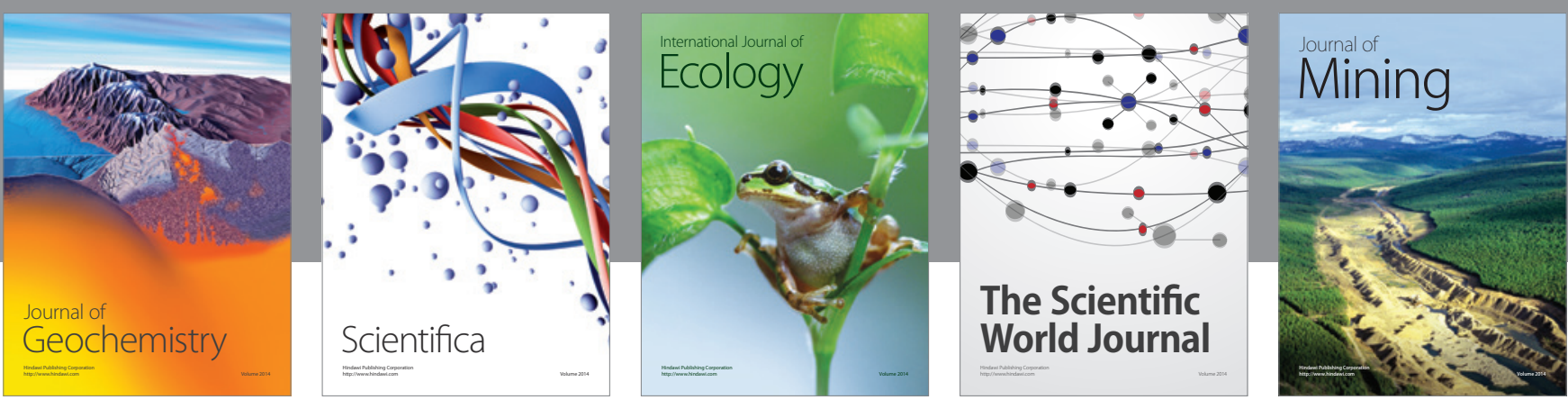

The Scientific World Journal
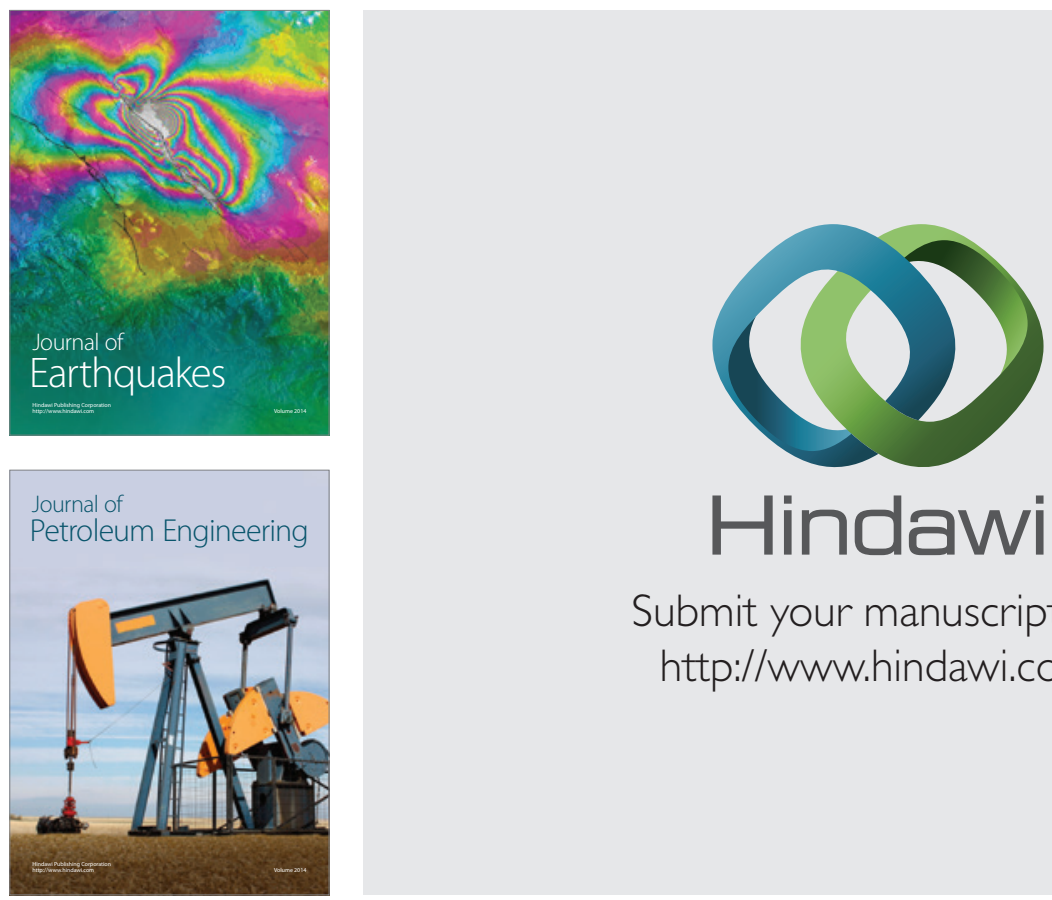

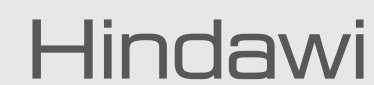

Submit your manuscripts at

http://www.hindawi.com
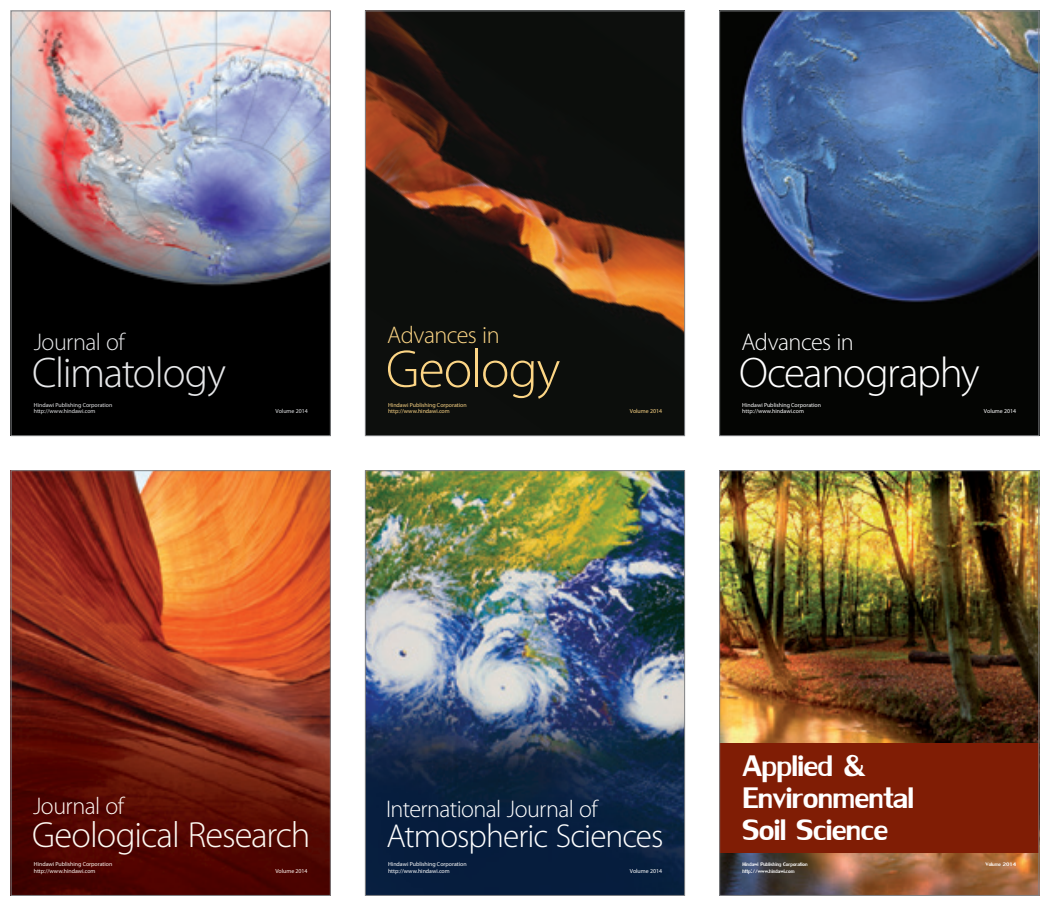
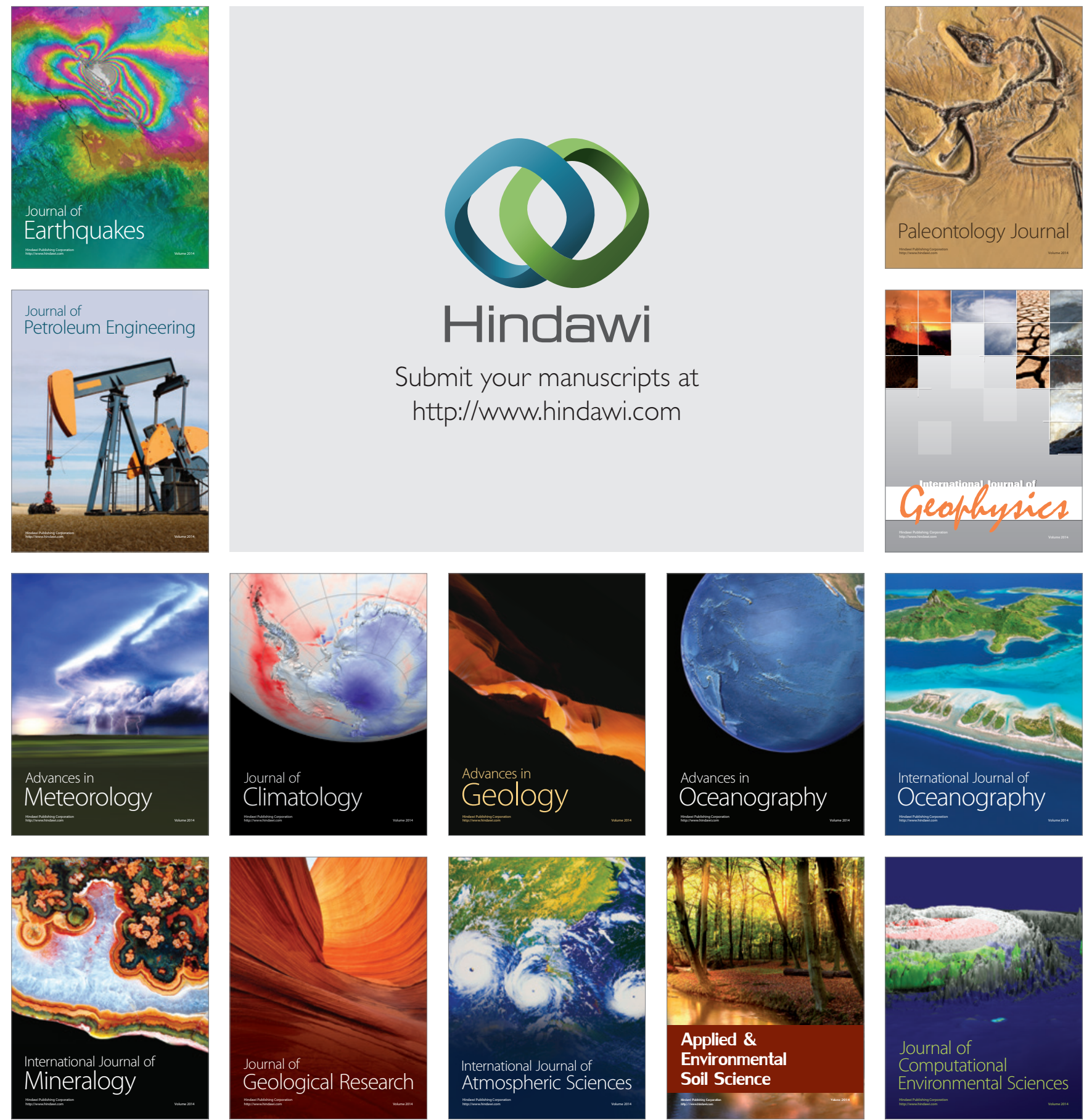